\title{
Study of morphology, chemical, and amino acid composition of red deer meat
}

Eleonora Okuskhanova ${ }^{1}$, Bahytkul Assenova ${ }^{1}$, Maksim Rebezov ${ }^{2,3}$, Kumarbek Amirkhanov ${ }^{1}$, Zhanibek Yessimbekov ${ }^{1}$, Farida Smolnikova ${ }^{1}$, Almagul Nurgazezova ${ }^{1}$, Gulnur Nurymkhan ${ }^{1}$ and Marilyne Stuart ${ }^{4}$

1. Department of Technology of Food and Light Industry Products, Shakarim State University of Semey, Semey City, Kazakhstan; 2. Department of Management of Technology Innovations and Veterinary Activity, Russian Academy of Staffing of Agro-industrial Complex, Moscow, Russia; 3. Department of Technologies of Production and Processing of Agricultural Products, Ural State Agrarian University, Yekaterinburg, Russia; 4. Canadian Nuclear Laboratories, Chalk River Laboratories, Chalk River, Ontario, Canada.

Corresponding author: Eleonora Okuskhanova, e-mail: eleonora-okushan@mail.ru,

Co-authors: BA: asenova.1958@mail.ru, MR: rebezov@ya.ru, KA: aspirant57@mail.ru, ZY: zyessimbekov@gmail.com, FS: smolnikovafarida@mail.ru, AN: almanya1975@mail.ru, GN: gulnu-n@mail.ru, MS: marilyne.stuart@cnl.ca.

Received: 19-01-2017, Accepted: 21-04-2017, Published online: 10-06-2017

doi: 10.14202/vetworld.2017.623-629 How to cite this article: Okuskhanova E, Assenova B, Rebezov M, Amirkhanov K, Yessimbekov Z, Smolnikova F, Nurgazezova A, Nurymkhan G, Stuart M (2017) Study of morphology, chemical, and amino acid composition of red deer meat, Veterinary World, 10(6): 623-629.

\begin{abstract}
Aim: The aim of this study was to evaluate red deer (maral) meat quality based on chemical composition, $\mathrm{pH}$, water-binding capacity (WBC), and amino acid content.

Materials and Methods: Maral meat surface morphology measurements were obtained by scanning electron microscopy. Active acidity $(\mathrm{pH})$ was determined by potentiometry. Samples were analyzed for WBC by exudation of moisture to a filter paper by the application of pressure. Chemical composition (moisture, protein, fat, and ash fractions) was obtained by drying at $150^{\circ} \mathrm{C}$ and by extraction, using ethylic ether, and ashing at $500-600^{\circ} \mathrm{C}$. The amino acid composition was obtained by liquid chromatography.

Results: Maral meat, with a pH of 5.85 and an average moisture content of $76.82 \%$, was found to be low in fat (2.26\%). Its protein content was $18.71 \%$ while its ash content was $2.21 \%$. The amino acid composition showed that lysine $(9.85 \mathrm{~g} / 100 \mathrm{~g})$, threonine $(5.38 \mathrm{~g} / 100 \mathrm{~g})$, and valine $(5.84 \mathrm{~g} / 100 \mathrm{~g})$ predominated in maral meat, while phenylalanine $(4.08 \mathrm{~g} / 100 \mathrm{~g})$, methionine $(3.29 \mathrm{~g} / 100 \mathrm{~g})$, and tryptophan $(0.94 \mathrm{~g} / 100 \mathrm{~g})$ were relatively low in maral meat compared to other meats. The average WBC was found to be $65.82 \%$ and WBC was found to inversely correlate with moisture content.
\end{abstract}

Conclusion: Low-fat content, high mineral content, and balanced amino-acid composition qualify maral meat as a worthy dietary and functional food.

Keywords: amino acid, composition, maral, red deer meat, quality, water-binding capacity.

\section{Introduction}

Nontraditional meat products are continually emerging on the market, notably products containing horse, deer, rabbit, ostrich, wild yak, and game meat [1-4]. Game meat tends to be preferred over the meat obtained from livestock animals [5]. The main reason for this is that game meat is considered a natural food. This is because wild animals are thought to feed as nature intended, and they are perceived as being strong (as they survived natural selection) and less stressed than livestock animals (as they live free and follow their instincts) [6,7].

Maral is one of the easternmost subspecies of red deer that is native to an area that covers part of Kazakhstan, China, Mongolia, and Russia [8]. Marals live in the Altai-Sayan mountains, southeast of

Copyright: Okuskhanova, et al. Open Access. This article is distributed under the terms of the Creative Commons Attribution 4.0 International License (http://creativecommons.org/licenses/ by/4.0/), which permits unrestricted use, distribution, and reproduction in any medium, provided you give appropriate credit to the original author(s) and the source, provide a link to the Creative Commons license, and indicate if changes were made. The Creative Commons Public Domain Dedication waiver (http:// creativecommons.org/publicdomain/zero/1.0/) applies to the data made available in this article, unless otherwise stated.
Kazakhstan and in Predbaikal (Russia). The Republic of Kazakhstan marals are mainly inhabiting the east part of Kazakhstan (Figure-1) [9] and, as of 2012, the maral population is estimated at 3500 animals [10]. Maral meat is considered game meat.

In addition to the meat, that will be discussed later, blood and antlers are obtained from maral and spotted deer. This is because young antlers contain substances which have tonic effects, increasing the general state of health of humans. Antlers are also a source of protein, fat, and mineral elements, such as calcium $(\mathrm{Ca})$, iron $(\mathrm{Fe})$, silicium, phosphorus $(\mathrm{P})$, sodium $(\mathrm{Na})$, and potassium $(\mathrm{K})$ [11]. The substance is also rich in amino acids such as glycine, proline, glutamic acid, lysine, leucine, and threonine [12]. Maral blood is of great pharmacological value. It can be used in the production of medicinal preparation, known as velvet antlers hematogen, for the treatment of nervous breakdown, metabolic disorder, catarrhs, gastritis, anemia, and other conditions [12]. Dried tails, leg tendons, penis, and 3-4 month embryos are also considered to have therapeutic value [13].

Maral meat is rich in minerals, essential amino acids, vitamins (5-10 times more than in beef), protein (it has a protein content of $18-20 \%$ ) and it is low in fat 
(its fat content varies between 1.1 and $3.9 \%$ and the meat has a low cholesterol content) [14]. Maral meat also contains bioactive substances, ferments and hormones which are considered beneficial. The caloric value of maral meat is 944-1154 kcal per $100 \mathrm{~g}$ [15]. Kaimbayeva [16] determined that, while for the most part the mineral composition of maral meat is equivalent to beef, some elements are found in greater amounts in maral meet compared to beef. Maral meat is richer in $\mathrm{Ca}$, fluorine, $\mathrm{Fe}$, copper $(\mathrm{Cu})$, zinc $(\mathrm{Zn})$, and chromium compared to beef [17]. Maral meat is also a very valuable source of Vitamins: $\mathrm{A}, \mathrm{B}, \mathrm{C}$, and $\mathrm{E}$; as well as minerals: $\mathrm{Fe}, \mathrm{K}, \mathrm{Ca}$, magnesium $(\mathrm{Mg}), \mathrm{Cu}$, $\mathrm{Zn}$, and selenium $[18,19]$. The meat contains bioactive substances such as ferments and hormones, which can be beneficial to the weakened body. The meat represents $55-60 \%$ of the weight of the animal [20].

Due to its high $\mathrm{Fe}$ concentration, maral meat has a distinctive smell and sweetness associated with a metal taste. Serine, aspartic acid, glutamic acid, low molecular and volatile fatty acids also play a major role in the development of the meat flavor [21]. As we will see later, there are also some morphological differences between maral meat and the meat of livestock animals.

The purpose of this study is to evaluate red deer (maral) meat quality based on chemical composition, $\mathrm{pH}$, water-binding capacity (WBC), and amino acid content.

\section{Materials and Methods}

\section{Sampling}

A total of $5 \mathrm{~kg}(2.5 \mathrm{~kg}$ from Ulan and $2.5 \mathrm{~kg}$ from Ust-Kamenogorsk city) of meat was collected for analysis. 10 samples of maral meat (Musculus longissimus dorsi) were obtained from the two local trade markets located in the Ulan settlement, and 20 samples from the three markets located in Ust-Kamenogorsk city. The markets are within the East Kazakhstan region (Figure-1). The meat was transported to the laboratory where it was stored at $2-3^{\circ} \mathrm{C}$. The next day, the meat samples were grinded, mixed, and immediately used for analysis.

\section{Surface morphology and pH measurements}

The surface morphology of the maral meat was studied using a scanning electron microscopy technique. The instrument used was a low-vacuum raster electron microscope "JSM-6390 LV" (JEOL, Japan). Active acidity $(\mathrm{pH})$ was determined using a potentiometer method. A pH-tester 340 (InfraspakAnalit, Russia) was used to obtain the information. This was done simply by dipping the two electrodes into a solution and taking a reading. The solution was prepared as follows: The meat samples was minced and mixed with (distilled-deionized water in the ratio 1 part of meat: 10 parts of water. The $\mathrm{pH}$ reading was obtained after $30 \mathrm{~min}$ of infusion at $20^{\circ} \mathrm{C}$.

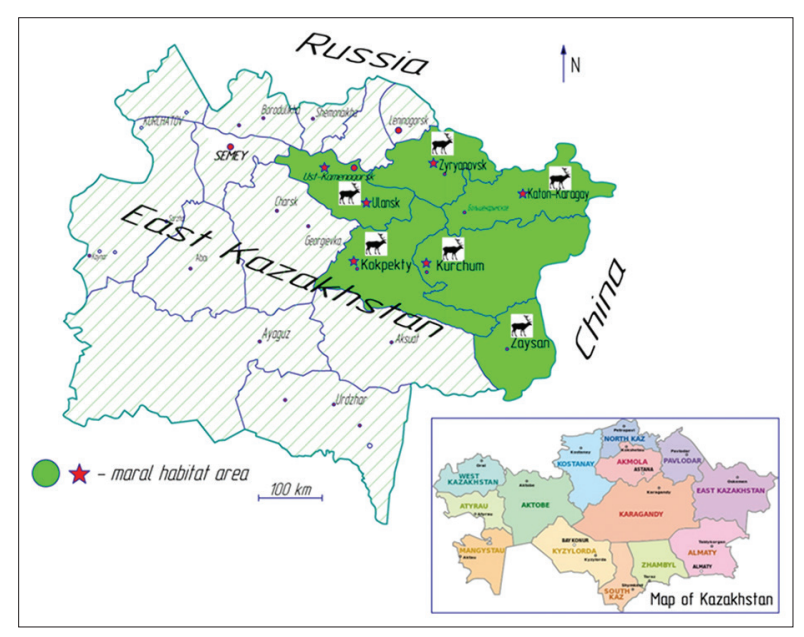

Figure-1: Maral habitat in East Kazakhstan.

\section{WBC}

The method used to determine the WBC of the samples is based on exudation of moisture to a filter paper by the application of pressure. The moisture absorbed by the filter paper is evaluated based on the spot area on the filter paper. Specifically, for each sample, $0.3 \mathrm{~g}$ of minced meat was placed on a 15-20 mm diameter disk plate on a Mettler Toledo electronic balance, (Mettler Toledo, Switzerland). The meat was then transferred onto an ash-free filter (Munktell Filter AB, Sweden) and placed on a glass or plexiglass plate. The sample was covered with the same kind of filter before a $1 \mathrm{~kg}$ load was carefully placed on top of the meat. The weight was left for $10 \mathrm{~min}$. Once removed, the top filter was pulled of and bound water was calculated, as described below (Equations a and $\mathrm{b}$ ). The filter was scanned using an Xpress M2070 scanner (SAMSUNG, Japan) after the contour of the wet spot was traced on the filter. The area was calculated using the "Compas-3D V-10" software [22].

$$
\begin{aligned}
& X_{1}=(A-8,4 B) \cdot 100 / m_{0}, \\
& X_{2}=(A-8,4 B) \cdot 100 / A ;
\end{aligned}
$$

Where $X_{l}$ - bound water content, expressed as $\%$ of meat;

$X_{2}$ - bound water content, expressed as $\%$ to total water;

$B$ - wet spot area, $\mathrm{cm}^{2}$;

$m_{0}$ - sample weight, mg;

$A$ - total content of moisture in the sample, mg.

\section{Chemical composition}

The determination of the chemical composition of meat was based on the determination of the following constituents: Moisture, fat, ash, and protein. To determine water content, a 2-3 g aliquot of each sample of meat was weighted to the nearest $0.001 \mathrm{~g}$ using a Mettler Toledo electronic balance (Mettler Toledo, Switzerland) and placed into a metallic cup (IngoLab, Russia). It was then dried for $1 \mathrm{~h}$, in a drying oven SNOL 67/350 (Umega, Latvia), at a temperature of $150^{\circ} \mathrm{C}$. The moisture content was calculated using 
Equation c, according to the standards GOST 979374 [23] and GOST R 51479-99 [24].

$x_{1}=\left(m_{1}-m_{2}\right) \cdot 100 /\left(m_{1}-m\right)$

Where, $x_{1}$ - moisture content, $\%$;

$m_{1}$ - weight of sample with cup before drying, g;

$m_{2}$ - weight of sample with cup after drying, g;

$m$ - weight of cup, g.

After moisture determination, each dried sample was moved to a glass cup. Then, $15 \mathrm{ml}$ of ethylic ether (Chemically pure $100 \%$, Skat, Kazakhstan) was poured into the glass cup and the contents were mixed for 3-4 min. During the extraction process, the ethylic ether containing the fat residues was poured out and replaced with fresh ethylic ether. After 4-5 repetitions, the ethylic ether was evaporated at room temperature. The cup containing the fat depleted sample was dried at $105^{\circ} \mathrm{C}$ for $10 \mathrm{~min}$. According to the standard GOST 23042-86 [25], the fat content was calculated using Equation $\mathrm{d}$.

$$
\begin{aligned}
& x_{2}=\left(m_{1}-m_{2}\right) \cdot 100 / m_{0} \\
& \text { Where, } x_{2}-\text { fat content, } \% \text {; } \\
& m_{1}-\text { weight of cup and dry sample before } \\
& \text { extraction, } \mathrm{g} \text {; } \\
& m_{2}-\text { weight of cup and sample after extraction, g; } \\
& m_{0}-\text { weight of cup, g. }
\end{aligned}
$$

To obtain the ash content, the sample from which the fat was extracted was placed into a weighted and preheated (to $150^{\circ} \mathrm{C}$ ) crucible $\left(50 \mathrm{~cm}^{3}\right.$, Mankor, Ukraine). Then, $1 \mathrm{ml}$ of $\mathrm{Mg}$ acetate (Purity 98\%, Labofarma, Kazakhstan) was added to the crucible, and the mixture was burned on an electric hot plate. After that, it was placed into a muffle furnace set at a temperature of $500^{\circ} \mathrm{C}-600^{\circ} \mathrm{C}$ (SNOL $7.2 / 1100$, Umega, Lithuania) for $30 \mathrm{~min}$. The ash content was calculated following Equation e:

$$
\begin{aligned}
& x_{3}=\left(m_{1}-m_{2}\right) \cdot 100 / m_{0} \\
& \text { Where, } x_{3}-\text { ash content, } \% \\
& m_{1}-\text { weight of ash, g; } \\
& m_{2}-\text { weight of } \mathrm{Mg} \text { oxide, obtained after the min- } \\
& \quad \text { eralization of Mg acetate, g; } \\
& m_{0}-\text { weight of sample, g. }
\end{aligned}
$$

The protein content was assayed according to the standard GOST 25011-81 [26] and calculated using Equation $\mathrm{f}$.

$$
x=100-\left(x_{1}+x_{2}+x_{3}\right)
$$

Where, $x$ - protein content, $\%$

$x_{1}$ - moisture content, $\%$;

$x_{2}-$ fat content, $\%$;

$x_{3}$ - ash content, $\%$.

Liquid chromatography was used to quantify amino acids. The instrument used was a "Shimadzu LC-20 Prominence" liquid chromatography system (Shimadzu, Japan) equipped with fluorometric and spectrophotometric detectors. The chromatographic column used was SUPELCO C18, $5 \mu \mathrm{m}$ (SigmaAldrich, USA) offering a surface area of $200 \mathrm{~m}^{2} / \mathrm{g}$. The chromatographic analysis was performed under a linear gradient with an eluent flow rate of $1.2 \mathrm{ml} / \mathrm{min}$, and the column was heated in an oven at $400^{\circ} \mathrm{C}$. Amino acids were detected using fluorometric and spectrophotometric detectors at wavelengths of $246 \mathrm{~nm}$ and $260 \mathrm{~nm}$ following acidic hydrolysis and treatment with a phenylisothiocyanate solution in isopropyl alcohol to give phenylthiohydantoins.

\section{Statistical analysis}

Differences between samples were evaluated using the t-test. The differences were considered to be statistically significant at $p \leq 0.05$. The statistical analysis was performed using the free software R 3.02 (R Core Team, 2013).

\section{Results and Discussion}

Images of the morphological microstructure of maral meat are presented in Figure-2. The maral muscle tissue longitudinal shear images show the length of the straight and curved muscle fibers. Images of the transversal sections show that each fiber has a polygonal structure. Looking at the muscle fiber size, it was noted that maral meat possesses a juiciness that is not seen in beef. In fact, the larger amount of moisture in maral meat compared to beef explains this difference [16]. Table-1 presents the moisture data obtained

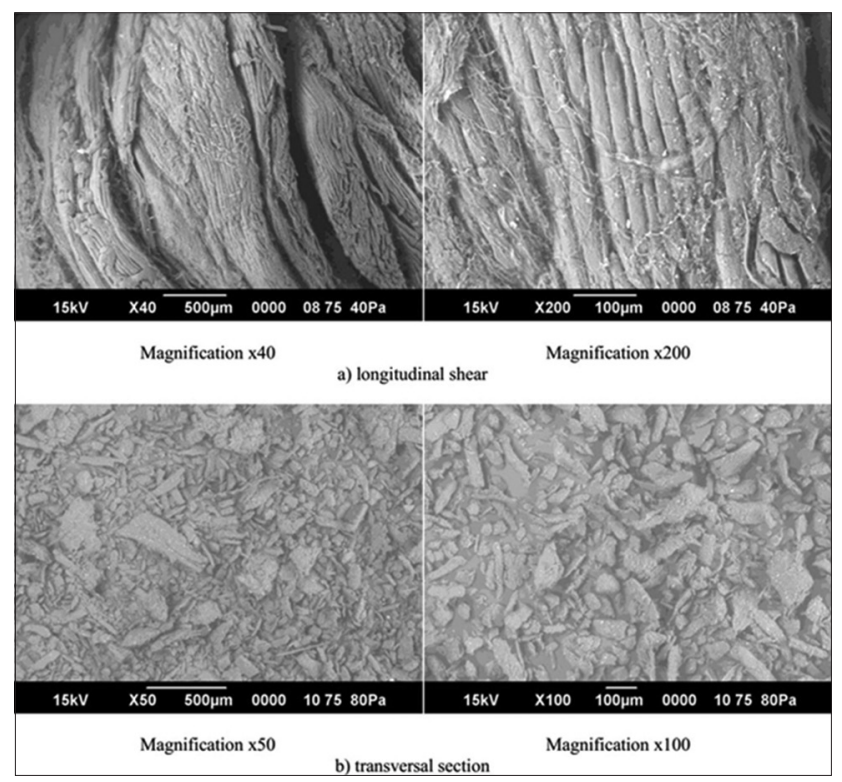

Figure-2: Images of longitudinal and transversal sections of maral muscle tissue obtained by scanning electron microscopy.

Table-1: Chemical composition of beef, horse and maral meat, \%.

\begin{tabular}{lcccc}
\hline Indicator & $\mathbf{n}$ & Beef [27] & $\begin{array}{c}\text { Horse } \\
\text { meat [28] }\end{array}$ & $\begin{array}{c}\text { Maral } \\
\text { meat }\end{array}$ \\
\hline Moisture & 10 & $73.81 \pm 0.98^{*}$ & $69.64 \pm 0.75^{*}$ & $76.82 \pm 1.16$ \\
Protein & 10 & $13.70 \pm 0.25^{*}$ & $19.58 \pm 0.34^{*}$ & $18.71 \pm 0.27$ \\
Fat & 10 & $10.29 \pm 0.17^{*}$ & $9.91 \pm 0.14^{*}$ & $2.26 \pm 0.03$ \\
Ash & 10 & $1.15 \pm 0.02 *$ & $1.00 \pm 0.01^{*}$ & $2.21 \pm 0.04$ \\
Energy & 10 & 147.4 & 167.1 & 91.04 \\
value (kcal) & & & & \\
\hline
\end{tabular}

*Indicate that the values are statistically different from the maral meat ( $t$-test, $\mathrm{p}<0.05$ ). Results are expressed as mean $\pm S D$. $n=$ number of samples, $S D=$ Standard Deviation 
for maral meat during this study and, for comparison, shows values that have been reported for beef and horse meat. Maral meat was found to contain significantly more moisture compared to the other two meat types. One of the important meat quality indicators is its moisture content. Juiciness, tenderness, losses during heat treatment (or cooking), and appearance are all dependent on the ability of meat to hold or bind water. As shown in Table-2, the average WBC for maral meat was $65.82 \%$ which was found to be lower than previously reported beef (69.02\%) [27] and horse meat $(67.88 \%)$ values [28]. As for the moisture content, the differences were statistically significant. The WBC values were inversely correlated to moisture content. Proteins in muscle tissue are likely modulating the WBC $[29,30]$.

In broad terms, the nutritional value of meat, however, depends on the quantitative ratios of moisture, protein, fat, and minerals. More specifically, it is also a function of the contents in essential amino acids, polyunsaturated fats, B vitamins as well as macro- and microelements. Tables- 1 and 2 summarize differences in chemical composition in terms of protein, fat, and ash contents between maral meat, beef and horse meat to allow for a comparison of their respective nutritional value. Table-1 presents information regarding the protein, fat, and ash contents and Table- 2 presents the $\mathrm{pH}$ data (Figure-3).

In comparison to the other meat types, maral meat was found to be low in fat. On average, maral meat's fat content was found to be $2.26 \%$ while $9.91 \%$ was obtained for horse meat [28] and $10.29 \%$ was obtained for beef [27]. Maral meat contains much less fat than beef and horse meat (by factors of 3.0 and 2.8 , respectively). Maral meat is very lean because the lipids are mainly deposited in the subcutaneous fat layer of the animal while, in the livestock animals, fat deposits are not only in the subcutaneous fat layer but also in the muscular fraction [31].

The protein content of maral meat, at $18.71 \%$, was found to be higher than beef (13.70\%) and lower than horse meat $(19.58 \%)$ [27,28].

A higher content of ash was obtained for maral meat (average of $2.21 \%$ ) compared to beef $(1.15 \%)$ [27] and horse meat $(1.00 \%)$ [28]. This demonstrates abundance of minerals. The results obtained in a previous study [14] showed that maral meat is a very suitable source of micronutrients such as: K-3045.30mg/kg,P-592.12mg/ $\mathrm{kg}, \mathrm{Mg}-224.07 \mathrm{mg} / \mathrm{kg}, \mathrm{Na}-217.94 \mathrm{mg} / \mathrm{kg}, \mathrm{Ca}-77.28 \mathrm{mg} /$ $\mathrm{kg}, \mathrm{Fe}-38.39 \mathrm{mg} / \mathrm{kg}$, aluminium - $36.58 \mathrm{mg} / \mathrm{kg}, \mathrm{Zn}-$ $30.04 \mathrm{mg} / \mathrm{kg}$, manga-nese- $6.92 \mathrm{mg} / \mathrm{kg}, \mathrm{Cu}-1.40 \mathrm{mg} / \mathrm{kg}$, and nickel- $0.30 \mathrm{mg} / \mathrm{kg}$. The average maral meat $\mathrm{pH}$ value was 5.85. This value was similar to values previously reported for horse meat and beef.

The chemical composition results, obtained in this study, were compared with other data reported in different sources (Table-3). According to the deer meat composition reported in other studies, the protein, fat
Table-2: pH and water-binding capacity of maral meat.

\begin{tabular}{lcccc}
\hline Value & $\mathbf{n}$ & Beef [27] & $\begin{array}{c}\text { Horse } \\
\text { meat [28] }\end{array}$ & $\begin{array}{c}\text { Maral } \\
\text { meat }\end{array}$ \\
\hline pH & 10 & $5.73 \pm 0.07$ & $5.84 \pm 0.06$ & $5.85 \pm 0.11$ \\
WBC, \% & 10 & $69.02 \pm 1.28 *$ & $67.88 \pm 0.82 *$ & $65.82 \pm 0.77$ \\
\hline
\end{tabular}

*Indicate that the values are statistically different from the maral meat ( $t$-test, $\mathrm{p}<0.05)$. Results are expressed as mean $\pm S D$. $n=$ number of samples, $S D=$ Standard Deviation, $\mathrm{WBC}=$ Water-Binding Capacity

Table-3: Chemical composition of deer meat previously reported in the literature.

\begin{tabular}{lcccc}
\hline Source & Moisture & Protein & Fat & Ash \\
\hline This study & 76.82 & 18.71 & 2.26 & 2.21 \\
Kaimbayeva, 2014 [16] & 78.2 & 17.4 & 3.2 & 1.2 \\
Ossipova, 2013 [31] & 74.9 & 21.6 & 2.5 & 1.0 \\
Ketselashvili et al., & 76.4 & 20.9 & 2.4 & 0.5 \\
2011 [5] & & & & \\
Strazdina et al., 2013 [33] & 70.6 & 22.4 & 1.9 & 1.1 \\
Malofeev et al., 2012 [34] & 76.7 & 21.4 & 0.3 & 1.6 \\
Okhremenko and Lee, & 78.0 & 20.0 & 1.1 & 0.9 \\
2005 [35] & - & 22.01 & 0.56 & 1.1 \\
Daszkiewicz et al., & - & & & \\
2009 [19] & 70.62 & 21.86 & 12.13 & 4.54 \\
Dahlan and N. Hanoon, & & & & \\
2008 [36] & 70.3 & 21.6 & 6.4 & 1.0 \\
Lisitsyn et. al., 2011 [37] & 78.5 & 19.4 & 1.4 & 0.7 \\
Jusupbekova, 2007 [38] & 78.5 \\
\hline
\end{tabular}

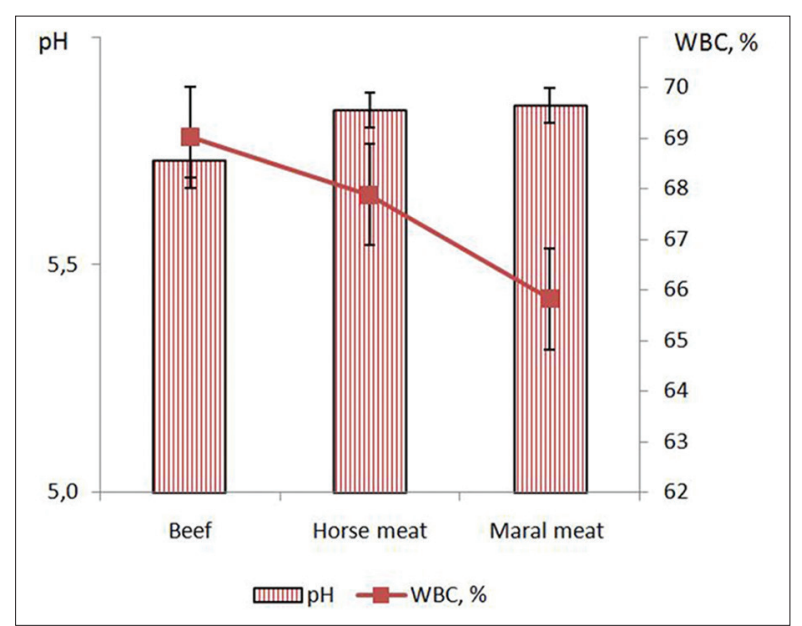

Figure-3: $\mathrm{pH}$ and water-binding capacity of beef, horse meat and maral meat.

and ash content ranged from $17.4 \%$ to $22.4 \%, 0.3 \%$ to $12.13 \%$ and 0.5 to $4.54 \%$, respectively. The results of this study, with average values of $18.71 \%, 2.26 \%$ and $2.21 \%$, respectively, compared very well. It stands to mention the work of Jussupbekova, published in 2007, [32] for which maral meat was sampled from East Kazakhstan in 2003-2006. This work is of particular interest as the maral samples were obtained from the same region as the samples obtained to carry out the current study. Jussupbekova showed a slightly higher protein content (19.4\%) and lower fat (1.4\%) and ash $(0.7 \%)$ contents, compared to the current study results. The differences in composition are likely due to factors such as differences in climatic conditions, 
landscape, living environment, feeding conditions, type of deer or meat cuts.

As the total protein content does not fully quantifies nutritional value, it is necessary to determine the amino acid composition. Amino acids are heterofunctional compounds which form the structure of proteins. They are organic compounds containing amine $\left(-\mathrm{NH}_{2}\right)$ and carboxyl $(-\mathrm{COOH})$ functional groups, along with a side chain (referred to as $\mathrm{R}$ group) which is specific to each amino acid. Thus, the balance and full-value of the amino acids in the proteins determine the physiological effect to the human body [38].

The amino acid content of maral meat, beef and horse meat is presented in Table-4. Although the content of some amino acids differ markedly depending on the meat cuts and the amount of associated connective tissues, in the current study, maral meat was found to contain more lysine, threonine and valine compared to the beef and horse meet. In maral meat, the isoleucine content is higher than in beef but is lower than in horse meat. Phenylalanine, methionine, and tryptophan represent a lesser proportion of the amino acids found in maral meat compared to beef and horse meat. Except for methionine and tryptophan, maral meat's composition in amino acid compares favorably to the Food and Agriculture Organization (FAO) scale.

Lysine, in which maral meat is rich in, is needed for normal bone shaping and children growth. It helps to better absorb $\mathrm{Ca}$ and contributes to the maintenance of normal nitrogen cycling in humans. Lysine is also involved in synthesis of antibodies, hormones, and ferments. It contributes to collagen formation and tissue recovery [39].

It is known that threonine, another amino acid that is found in high levels in maral meat, improves the cardiovascular and immune systems as well as liver condition. Furthermore, threonine is involved in glycine and serine synthesis. This amino acid strengthen the connective tissues and muscles, including the heart muscle [38].

Tryptophan, which is found in greater amounts in beef and horse meat compared to maral meat, is a factor of vitamin PP synthesis. A deficiency in this amino acid can cause pellagra. A tryptophan imbalance can lead to serious illnesses such as tuberculosis, cancer, and diabetes [40]. Tryptophan is an essential amino acid that is usually present in lean tissue and in lesser amounts in connective tissue and muscles, which are rich in oxyproline [41].

Methionine, also found in greater quantities in beef and horse meat compared to maral meat, is one of the main building blocks in the human body and it is essential to prevent vitamin B12 deficiency [42].

One important factor to consider during the formulations of food products is the biological value of the proteins that depends on the balance of amino acid. As the human body is only able to produce nine (histidine and the 8 listed in Table- 4 ) of the 22 amino acids, a deficiency in even one of the essential amino acids will lead to the failure of the protein synthesis and other biological substances [43]. Thus, the daily nutrition should contain enough of these amino acids $[39,44]$. According to the data presented in Table-4, the maral meat contains $42.61 \mathrm{~g}$ of amino-acids per $100 \mathrm{~g}$ of meat which is higher than beef but less than horse meat.

\section{Conclusion}

Maral meat was found to have a low fat content, high mineral content, and balanced amino-acid composition. This qualifies maral meat as a good dietary and functional food. Because of the wide use of beef in the production of meat products, the quantity of fat consumed is relatively high. When meat represents a large fraction of the diet, leaner alternative to beef, like maral meat, are desirable. Using maral meat in the formulations of meat products could therefore contribute to decreasing fat intake while increasing nutritive and biological value.

\section{Authors' Contributions}

This work came from active collaboration between researchers: EO, BA, MR, designed the study, developed the methodology, performed the analysis, and wrote the manuscript. ZY conducted the scanning electron microscope analyses and assisted with data analysis. FS, AN, GN performed the chemical and amino acid composition determinations. MS, KA provided helpful feedback on an early draft of the paper. MS proofread and corrected the English. All authors read and approved the final manuscript.

Table-4: Essential amino acids content in meat of slaughtered animal, g/100 g of product.

\begin{tabular}{|c|c|c|c|c|c|c|c|c|}
\hline \multirow[t]{2}{*}{ Essential amino acids } & \multicolumn{2}{|c|}{ FAO scale } & \multicolumn{2}{|c|}{ Beef [27] } & \multicolumn{2}{|c|}{ Horse meat [28] } & \multicolumn{2}{|c|}{ Maral meat } \\
\hline & $\mathrm{g} / 100 \mathrm{~g}$ & AS, $\%$ & $\mathrm{~g} / 100 \mathrm{~g}$ & AS, $\%$ & $\mathrm{~g} / 100 \mathrm{~g}$ & AS, $\%$ & $\mathrm{~g} / 100 \mathrm{~g}$ & AS, $\%$ \\
\hline Valine & 5.0 & 100 & 5.0 & 100 & 5.5 & 110 & 5.84 & 119 \\
\hline Isoleucin & 4.0 & 100 & 4.8 & 120 & 6.7 & 154 & 5.83 & 146 \\
\hline Leucine & 7.0 & 100 & 8.1 & 116 & 8.3 & 119 & 7.40 & 106 \\
\hline Lysine & 5.5 & 100 & 8.9 & 162 & 8.2 & 150 & 9.85 & 179 \\
\hline Methionine & 3.5 & 100 & 3.5 & 100 & 3.7 & 106 & 3.29 & 94 \\
\hline Threonine & 4.0 & 100 & 4.6 & 115 & 4.7 & 118 & 5.38 & 135 \\
\hline Tryptophan & 1.0 & 100 & 1.1 & 110 & 1.2 & 120 & 0.94 & 94 \\
\hline Phenylalanine & 6.0 & 100 & 4.5 & 75 & 5.5 & 92 & 4.08 & 68 \\
\hline Total & 36.0 & & 40.5 & & 43.8 & & 42.61 & \\
\hline
\end{tabular}

AS=Amino acid score 


\section{Acknowledgments}

This research received no grants from funding agencies in the public, commercial, or not-forprofit sectors. The authors would like to thank the staff of the engineering laboratory "Scientific Center of Radioecological Research" of Shakarim State University in Semey for conducting the analysis.

\section{Competing Interests} interests.

The authors declare that they have no competing

\section{References}

1. Zotte, A.D. and Szendrö, Z. (2011) The role of rabbit meat as functional food. Meat Sci., 88(3): 319-331.

2. Antipova, L.V., Gizatov, A.Y. and Zubairova, L.A. (2004) The ways of rational use of nontraditional meat with application of biotechnology treatments methods. Ration. Nutr. Food Addit. Biostimulators, 3: 21-24.

3. Naveen, Z., Reddy, P.M. and Reddy, K.P. (2006) Changes in the quality of duck meat sausages during frozen storage. J. Food Sci. Technol. Mysore, 43(3): 247-250.

4. Soriano, A., Cruz, B., Gomez, L., Mariscal, C. and Ruiz, A.G. (2006) Proteolysis, physicochemical characteristics and free fatty acid composition of dry sausages made with deer (Cervus elaphus) or wild boar (Sus scrofa) meat: A preliminary study. Food Chem., 96(2): 173-184.

5. Ketselashvili, D.V., Myshalova, O.M., Seregin, S.A. and Marchenko, S.V. (2011) Chemical composition and technological properties of Maral meat. Meat Ind., 3: 38-41.

6. Hoffman, L.C. and Wiklund, E. (2006) Game and venison-meat for the modern consumer. Meat Sci., 74(1): 197-208.

7. Zomborszky, Z., Szentmihály, G., Sarudi, I., Horn, P. and Szabó, C.S. (1996) Nutrient composition of muscles in deer and boar. J. Food Sci., 61: 625-627.

8. Parés-Casanova, P.M., Korzhikenova, N., Sambetbaev, A. and Iglikov, O. (2014) Fitting growth with the von Bertalanffy growth function: A comparison of two captive Maral populations. Glob. J. Anim. Sci. Res., 3(1): 166-170.

9. Kaimbaeva, L.A. and Gurinovich, G.V. (2016) Study of autolytic changes in red deer meat and beef. Indian J. Sci. Technol., 9(30): Available from http://www.indjst.org/index. php/indjst/article/viewFile/98747/72423. Last Accessed on 16-12-2016.

10. Korzhikenova, N.O., Sambetbaev, A.A. and Iglikov, O.D. (2014) Maral deer meat productivity and meat quality when using the different types of diets. Biosci. Biotechnol. Res. Asia, 11: 51-58.

11. Giżejewska, A., Nawrocka, A., Szkoda, J., Żmudzki, J., Jaroszewski, J. and Giżejewski, Z. (2016) Variations of selected trace element contents in two layers of red deer antlers. J. Vet. Res., 60: 467-471.

12. Korzhikenova, N., Sambetbaev, A., Iglikov, O. and Casanova, P.M.P. (2014) A limit for antler length in captive Marals. Int. J. Morphol., 32(2): 568-570.

13. Okhremenko, V.A. (2006) Comparative Analysis of Meat Quality Farmed and Wild Deer. PhD Thesis, Barnaul.

14. Assenova, B., Okuskhanova, E., Rebezov, M., Korzhikenova, N., Yessimbekov, ZH. and Dragoev, S. (2016) Trace and toxic elements in meat of Maral (red deer) grazing in Kazakhstan. Res. J. Pharm. Biol. Chem. Sci., 7(1): 1425-1433.

15. Okuskhanova, E., Assenova, B., Rebezov, M., Yessimbekov, Z., Kulushtayeva, B., Zinina, O. and Stuart, M. (2016) Mineral composition of deer meat pate. Pak. J. Nutr., 15(3): 217-222.

16. Kaimbayeva, L.A. (2014) Research and Practice Aspects of Processing and Quality Evaluation of Maral Meat and
Slaughtering Products. PhD Thesis. East Siberia State University of Technology and Management, Ulan Ude.

17. Uzakov, Y.M. and Kaimbayeva, L.A. (2015) Using of meat and by-products of Marals in the production of meat products. Meat Ind., 8: 40-43.

18. Wiklund, E., Dobbie, P., Stuart, A. and Littlejohn, R.P. (2010) Seasonal variation in red deer (Cervus elaphus) venison (Musculus longissimus dorsi) drip loss, calpain activity, colour and tenderness. Meat Sci., 86(3): 720-727.

19. Daszkiewicz, T., Janiszewski, P. and Wajda, S. (2009) Quality characteristics of meat from wild red deer (Cervus Elaphus L.) hinds and stags. J. Muscle Foods, 20: 428-448.

20. Dzięciołowski, R., Babińska-Werka, J., Wasilewski, M. and Goszczyński, J. (1996) Physical condition of red deer in a high density population. Acta Theriol., 41(1): 93-105.

21. Polak, T., Rajar, A., Gašperlin, L. and Zlender, B. (2008) Cholesterol concentration and fatty acid profile of red deer (Cervus elaphus) meat. Meat Sci., 80: 864-869.

22. Kabulov, B.B., Kakimov, A.K., Ibragimov, N.K. and Yessimbekov, Z.S. (2014) Method of Determining the Water Binding Capacity of Food Products. Patent \#28152. Issued February, 17, 2014.

23. GOST 9793-74. (2010) Official Method: Meat Products. Method of Moisture Determination. Standardinform, Moscow.

24. GOST R 51479-99. (2010) Official Method: Meat and Meat Products. Method for Determination of Moisture Content. Standardinform, Moscow.

25. GOST 23042-86. (2010) Official Method: Meat and Meat Products. Method of Fat Determination. Standardinform, Moscow.

26. GOST 25011-81. (2010) Official Method: Meat and Meat Products. Method of Protein Determination. Standardinform, Moscow.

27. Skurikhin, I.M. and Tutelyan, V.A. (2002) Chemical Composition of Russian Food Products. Deli Print, Moscow.

28. Toleuov, Y.T. (1986) Horse Meat Processing. Agropromizdat, Moscow.

29. Cheng, Q. and Sun, D.W. (2008) Factors affecting the water holding capacity of red meat products: A review of recent research advances. Crit. Rev. Food Sci. Nutr., 48(2): 137-159.

30. Karl, O.H. (2004) Water-holding capacity of meat. In: Te Pas, M.F.W., Everts, M.E. and Haagsman, H.P., editors. Muscle Development of Livestock Animals. CAB International, Wallingford, UK. p389-400.

31. Ossipova, M.O. (2013) Research and Design of Fermented Product from Maral Meat by Accelerating Method of Production. Abstract of a PhD-Thesis. Kemerovo.

32. Jussupbekova, N.M. (2007) Veterinary-Sanitary Value of Maral Meat in Case of Strongylatosis and Eimeriosis Invasion. Abstract of PhD-Thesis. Kazakh National Agrarian University, Almaty, Kazakhstan.

33. Strazdina, V., Jemeljanovs, A., Sterna, V. and Ikauniece, D. (2013) Nutrition value of deer, wild boar and beaver meat hunted in Latvia. $2^{\text {nd }}$ International Conference on Nutrition and Food Sciences IPCBEE. Vol. 53. p71-76.

34. Malofeev, Y.M. and Poltev, A.V. (2009) Characteristic of some hind limb muscles of Maral due to meat productivity. Bull. Altai State Agrarian Univ., 2(52): 40-42.

35. Okhremenko, V.A. and Lee, S.S. (2005) Meat quality of wild deer of Altai region. Bull. Altai State Agrarian Univ., 4(20): 27-30.

36. Dahlan, I. and Hanoon, N.A.N. (2008) Chemical composition, palatability and physical characteristics of venison from farmed deer. Anim. Sci. J., 79: 498-503.

37. Lisitsyn, A.B., Chernukha, I.M., Kuznetsova, T.G., Orlova, O.N. and Mkrtichyan, V.S. (2011) Chemical composition of meat. Look-up tables of chemical, amino-acid, fatty acid, vitamin, macro - And microelements compositions and nutritive (energy and biological) value of meat. VNIIMP, Moscow. 
38. Bhutta, Z.A. (1999) Protein: Digestibility and availability. In: Encyclopedia of Human Nutrition. Academic Press, San Diego. p1646-1656.

39. Garaeva, S.N., Redkozubova, G.V. and Postolati, G.V. (2009) Aminoacids in living organism. Science Academy Publ., Kishinev, Moldova.

40. Schaafsma, G. (2000) The protein digestibility - Corrected amino acid score. J. Nutr., 130: 1865-1867.

41. Okuskhanova, E.K., Asenova, B.K., Rebezov, M.B., Omargalieva, N.K. and Yessimbekov, Z.H.S. (2015) Aminoacid composition of pâté based on Maral meat and protein enricher. Food Process. Tech. Technol., 39(4): 71-79.

42. Cornet, M. and Bousset, J. (1999) Free amino acids and dipeptides in porcine muscles: Differences between 'red' and 'white' muscles. Meat Sci., 51: 215-219.

43. Feiner, G. (2006) Meat Products Handbook. Wood Head Publishing Limited, Cambridge, England.

44. Montowska, M. and Pospiech, E. (2013) Species-specific expression of various proteins in meat tissue: Proteomic analysis of raw and cooked meat and meat products made from beef, pork and selected poultry species. Food Chem., 136(3-4): 1461-1469.

$* * * * * * * *$ 